\title{
The influence of feeding raw vs extruded soyabean supplemented or unsupplemented with sulphur amino acids on performance, pancreatic trypsin activity and morphological parameters of the jejunum in rats
}

\author{
H. Leontowicz ${ }^{1}$, M. Leontowicz ${ }^{1}$, M. Biernat ${ }^{2}$, M.A. Gralak ${ }^{1}$, \\ H. Kostyra ${ }^{3}$ and J. Czerwiński ${ }^{1}$ \\ 'Department of Physiology, Biochemistry, Pharmacology' and Toxicology, \\ ${ }^{2}$ Department of Anatomy, Histology and Embryology, Faculty of Veterinary Medicine. \\ Warsaw Agricultural University \\ Nowoursynowska 166, 02-787 Warszawa, Poland \\ ${ }^{3}$ Division of Food Science, Institute of Animal Reproduction and Food Research, \\ Polish Academy of Sciences \\ Tuwima 10, 10-718 Olsztyn, Poland
}

\begin{abstract}
The effect of extrusion of soyabean seeds and sulphur amino acid (AA) supplementation on trypsin inhibitor (TI) and lectin activity, and on the histology and microbiology of the jejunum were studied. Wistar rats were fed semi-purified diets containing $10 \%$ of soyabean seeds: raw (R) or extruded at $160^{\circ} \mathrm{C}(\mathrm{E})$ and unsupplemented or supplemented with $0.3 \%$ (AA) (met+cys, $1: 1$ ). Extrusion reduced TI activity in seeds from 25.0 to $11.8 \mathrm{TUI} / \mathrm{mg}$. Extrusion of soyabean seeds also reduced agglutination activity against human red blood cells from 1:1600 to 1:100 (group $\mathrm{AB}$ ), from $1: 800$ to $1: 100$ (group 0), from $1: 800$ to $1: 50$ (group A), and from 1:400 to 1:50 (group B). Extrusion of soyabean seeds improved $(\mathrm{P}<0.05)$ performance and decreased pancreas weight $(0.40$ vs $0.50 \% \mathrm{BW}$ ). Extrusion increased $(\mathrm{P}<0.05$ ) pancreatic trypsin activity $(3495 \mathrm{vs} 590 \mathrm{l} \mathrm{U} / 100 \mathrm{~g}$ protein), improved the morphology of the jejunum, and reduced the $E$. coli count. The influence of AA in the group fed raw seeds on performance and morphological gut parameters was even better than the effect of extrusion.
\end{abstract}

KEY WORDS: soyabean, lectins, trypsin inhibitors, pancreas, small intestine, rats 


\section{INTRODUCTION}

Lectins and enzyme inhibitors interfere with digestion, change the bioavailability of nutrients and depress growth rate (Liener, 1994). Soyabean lectins may agglutinate animal and human red blood cells (RBC) in vitro (Jaffe and Seldl, 1992), bind to the brush-border and induce its growth, and also reduce absorption of nutrients through the intestinal wall (Bardocz et al., 1995). Protease inhibitors and lectins may also induce pancreatic enlargement. Extrusion of soyabean seeds partly eliminates lectins and trypsin inhibitor activity. Feeding raw soyabean to rats aggravates the its deficiency in sulphur amino acids (Iwai et al., 1988), which can be partly overcome by supplementation with synthetic forms of amino acids.

The aim of our study performed on rats was to estimate the effect of extrusion and amino acid supplementation of diets with soybean seeds on protein digestibility, pancreatic trypsin activity, morphometry of the jejunal mucosa, and total count of mucosa-colonizing bacteria.

\section{MATERIAL AND METHODS}

\section{Animals and diets}

Male Wistar rats of about $86 \pm 6 \mathrm{~g}$ were divided into four groups of 10 rats. For 28 days all groups received ad libitum semi-purified diets containing (\%): wheat starch, 64.3; casein, 10; cellulose, 1; soyabean oil, 10; mineral-vitamin premix, 4.7 (NAS, 1972) and 10\% of soyabean (Glycine max. L.- imported from Austria) seeds (S) raw (R) or extruded (E) (extruder INSTA-PRO-600, exposition time $30-60 \mathrm{~s}$, temp. $160^{\circ} \mathrm{C}$ ), without or with $0.3 \%$ sulphur amino acids (AA) (cys+met, 1:1).

Rats were kept in individual plastic cages at a constant temperature $\left(24 \pm 1{ }^{\circ} \mathrm{C}\right)$ with $12 \mathrm{~h}$ light-dark cycle. Digestibility of dry matter and crude protein was estimated in the third week (5-day collection).

\section{Measurements}

Trypsin inhibitor activity (TIA) (Valdebouze et al., 1980) was estimated in raw and extruded soyabean seeds.

Lectins were extracted from raw and extruded seeds according to Paredes-Lopez et al. (1989). Lectin agglutination of human red blood cells RBC (groups 0, A, B, AB) was tested according to Liener (1989). Trypsin activity (Erlanger et al., 1961) and protein content (Lowry et al., 1951) in the pancreas were determined. 
Morphometric analyses of small intestine mucosa (jejunum) were performed. For this purpose, $2 \mathrm{~cm}$ long segments of jejunum were collected and fixed with Bouin's solution, dehydrated, put in xylen, embedded in paraffin, and sectioned using a microtome (Leitz 1512, Austria). Crypt depth, villi length and width, and tunica mucosa thickness were measured.

For bacteriology, a $1 \mathrm{~g}$ section of small intestine rinsed with saline was homogenized (Stomacher 400-Lab, Blender, UK), and inoculated onto an enriched agar plate for total bacteria count and Mac Conkey's plate for E. coli number determination.

\section{Statistical analysis}

The results were evaluated by ANOVA and differences between arithmetic means by the Tukey range test.

\section{RESULTS}

Lectins extracted from raw and extruded soyabean seeds agglutinated human red blood cells. The highest agglutination of human erythrocytes was found for blood groups $A B, O$ and $A$. After extrusion, agglutination activity was sixteen times lower in groups $\mathrm{AB}$ and $\mathrm{A}$ and eight times lower in blood groups $\mathrm{O}$ and $\mathrm{B}$ (Table 1).

Trypsin inhibitor activity in raw soyabcan was $25 \mathrm{TIU} / \mathrm{mg}$, after extrusion this activity amounted $11.8 \mathrm{TIU} / \mathrm{mg}$ (Table 1 ).

TABLE 1

Trypsin inhibitors and haemagglutination titre of protein extract from soyabean seeds

\begin{tabular}{lccccc}
\hline \multirow{2}{*}{$\begin{array}{l}\text { Soyabean } \\
\text { sceds }\end{array}$} & $\begin{array}{c}\text { Trypsin inhihibitors } \\
\text { TIU/mg }\end{array}$ & \multicolumn{4}{c}{ Haemagglutination titre of human red blood cells } \\
group
\end{tabular}

1:50, 1: 100, 1:200, 1:400,1:800, 1: 1600-dilution of initial $(1 \mathrm{mg} / \mathrm{ml})$ protein extract

The protein content of the diets was $13.3,13.0,13.7$ and $11.0 \%$ on a DM basis in SR, SE, SRAA, and SEAA, respcctively. Extrusion and AA supplementation each positively $(\mathrm{P}<0.05)$ influenced performance (Table 2$)$. Extrusion and $A A$ combined did not have a synergic effect. 
TABLE 2

The influence of soyabean extrusion and amino acids supplementation on performance, dry matter and protein digestibility in rats $(\mathrm{n}=10)$

\begin{tabular}{lrrrr}
\hline Item & Diet SR & Diet SE & Diet SRAA & Dict SEAA \\
\hline Food intake, g/d & $10.7 \pm 1.6^{\mathrm{a}}$ & $12.5 \pm 1.1^{\mathrm{b}}$ & $13.9 \pm 0.9^{\mathrm{c}}$ & $12.9 \pm 1.6^{\mathrm{bc}}$ \\
Body gain, g/d & $2.7 \pm 0.4^{\mathrm{a}}$ & $3.7 \pm 0.7^{\mathrm{b}}$ & $5.0 \pm 0.7^{\mathrm{c}}$ & $3.8 \pm 1.0^{\mathrm{b}}$ \\
FER, g/g & $3.9 \pm 0.5^{\mathrm{c}}$ & $3.4 \pm 0.4^{\mathrm{b}}$ & $2.8 \pm 0.3^{\mathrm{a}}$ & $3.4 \pm 0.5^{\mathrm{b}}$ \\
& & & & \\
Digestibility, \% & & & & \\
$\quad \begin{array}{l}\text { dry matter } \\
\text { crude protein }\end{array}$ & $93.8 \pm 1.1$ & $93.4 \pm 0.9$ & $93.4 \pm 0.9$ & $93.1 \pm 0.5$ \\
\hline
\end{tabular}

a.b.c means in the rows tagged with different letters differ significantly at $\mathrm{P}<0.05$

1 faba bean raw

2 faba bean extruded

3 faba bean row + amino acids

4 faba been extruded + amino acids

Extrusion and AA supplementation decreased relative pancreatic weight. Trypsin activity in the pancreas was lower $(\mathrm{P}<0.05)$ in the group receiving the dict with raw soyabean than in rats fed diet $\mathrm{SE}$ (Table 3 ).

TABLE 3

The influence of soyabean extrusion and amino acids supplementation on pancreatic paramerters in rats $(n=10)$

\begin{tabular}{lcccc}
\hline Item & Diet SR & Diet SE & Dict SRAA & Diet SEAA \\
\hline Pancreas, \% BW & $0.50 \pm 0.13^{\mathrm{b}}$ & $0.40 \pm 0.07^{\mathrm{a}}$ & $0.38 \pm 0.10^{\mathrm{a}}$ & $0.33 \pm 0.07^{\mathrm{a}}$ \\
Trypsin activity, & & & & \\
U/100 g protein & $3495 \pm 1137^{\mathrm{a}}$ & $5901 \pm 1756^{\mathrm{b}}$ & $4581 \pm 1485^{\mathrm{ab}}$ & $4870 \pm 1327^{\mathrm{b}}$ \\
Protein, mg/organ & $5.52 \pm 1.47^{\mathrm{b}}$ & $5.54 \pm 1.30^{\mathrm{b}}$ & $5.12 \pm 1.79^{\mathrm{b}}$ & $3.49 \pm 1.14^{\mathrm{b}}$ \\
\hline
\end{tabular}

a,b means in the rows tagged with different letters differ significantly at $\mathrm{P}<0.05$

$1.2,3,4$ as in Table 2

Extrusion of soyabcan seeds and AA supplementation of raw soya increased $(\mathrm{P}<0.05)$ crypt depth, villi length and width, as well as thickness of the tunica mucosa (Table 4). Total culturable bacterial count was similar in all groups and varied from 4.8 (SEAA) to $5.9 \log$ CFU/g (SRAA). The E. coli count was higher $(\mathrm{P}<0.05)$ in both groups fed raw seeds (SR and SRAA) than in the SEAA group (Table 5). 
TABLE 4

Morphometry analysis of the small intestine (jejunum) of rats $(n=10)$

\begin{tabular}{lllcc}
\hline ltem & Diet SR' & Diet SE $^{2}$ & Diet SRAA $^{3}$ & Diet SEAA \\
\hline Crypt deptl,$\mu \mathrm{m}$ & $131 \pm 3^{\mathrm{a}}$ & $160 \pm 6^{\mathrm{b}}$ & $171 \pm 6^{\mathrm{c}}$ & $154 \pm 3^{\mathrm{b}}$ \\
Villi length, $\mu \mathrm{m}$ & $308 \pm 6^{\mathrm{a}}$ & $344 \pm 12^{\mathrm{c}}$ & $347 \pm 12^{\mathrm{c}}$ & $328 \pm 9^{\mathrm{b}}$ \\
Villi width, $\mu \mathrm{m}$ & $102 \pm 6^{\mathrm{a}}$ & $116 \pm 3^{\mathrm{c}}$ & $108 \pm 3^{\mathrm{b}}$ & $118 \pm 6^{\mathrm{c}}$ \\
Thickness of tunica mucosa, $\mu \mathrm{m}$ & $447 \pm 12^{\mathrm{a}}$ & $499 \pm 18^{\mathrm{c}}$ & $528 \pm 15^{\mathrm{d}}$ & $479 \pm 12^{\mathrm{b}}$ \\
\hline
\end{tabular}

u.b.c means in the raws tagged with different letter differ significantly at $P<0.05$ and $S D$ 1.2 .3 .4 as in Table 2

TABLE 5

Microbiological parameters of jejunum of rats $(n=7)$

\begin{tabular}{lccc}
\hline Diets & $\begin{array}{c}\text { Total culturable bacterial count } \\
\log \mathrm{CFU} / \mathrm{g}\end{array}$ & $\begin{array}{c}\text { E. coli } \\
\log \mathrm{CFU} / \mathrm{g}\end{array}$ & $\begin{array}{c}\text { E. coli/total culturable } \\
\text { bacterial count }\end{array}$ \\
\hline $\mathrm{SR}^{1}$ & $5.51 \pm 0.63$ & $3.44 \pm 1.56^{\mathrm{b}}$ & 0.624 \\
$\mathrm{SRAA}^{3}$ & $5.90 \pm 1.74$ & $2.02 \pm 1.41^{\mathrm{b}}$ & 0.342 \\
$\mathrm{SEAA}^{4}$ & $4.80 \pm 1.07$ & $1.00 \pm 0.02^{\mathrm{*}}$ & 0.208 \\
\hline
\end{tabular}

* CFU - colony forming unit

a.b means in the raws tagged with different letter differ significantly at $\mathrm{P}<0.05$

$1.3,4$ as in Table 2

\section{DISCUSSION}

Thermolabile ANFs (trypsin inhibitors, lectin) present in legumes limit their feeding usefulness. Extrusion of soyabean seeds at $160^{\circ} \mathrm{C}$ reduced $\mathrm{TI}$ activity by $53 \%$ and partly reduced lectin activity. The greatest affinity for $A B$ antigenic determinants of $\mathrm{RBC}$ suggests that $\mathrm{A}$ and $\mathrm{B}$ blood group determinants may contribute to the hemagglutination process. A similar affinity of group $A B$ for leguminous protein extracts from raw soyabean, pea and faba bean was also shown by Kostyra et al. (1999) and for pea lectins by Leontowicz et al. (2000). Lowering TI and lectin activity by different technologies improved the nutritional value of legumes in many studies (Liener, 1994; Armour et al., 1998; Leontowicz et al., 2001 ) as it did in our study too (Table 2). The favourable effect of the AA added to SR on performance, is in agreement with the results of Gumbmann and Friedman (1987). The decline in pancreas weight and increase of pancreatic trypsin activity in rats fed the SE diet (Table 3) was similar to results obtained in our previous study (Leontowicz et al., 2001).

Bardocz et al. (1995) reported similar effects of soyabean lectins on adherence to enterocyte microvilli, their atrophy and morphological changes in the small 
intestine wall as those presented in this study. Changes in crypt depth in jejunal mucosa in rats fed SE and SRAA diets suggest increased proliferative processes in the mucosa epithelium. Both extrusion of seeds and sulphur AA supplementation induced clongation of villi and increased the thickness of the tunica mucosa of the jejunum. The E. coli count depended on the lectin activity in seeds, as partial inactivation of lectins decreased the $E$. coli count in the jejunum.

The positive relation between $E$. coli count, lectin intake and malabsorption of nutrients in the small intestine was observed by Pusztai (1993) and Leontowicz et al. (2000).

\section{CONCLUSIONS}

The hemagglutination (HA) titer of raw soyabean seeds is the highest towards human $\mathrm{RBC}$ group $\mathrm{AB}$, after extrusion it decreased in blood groups $\mathrm{AB}$ and $\mathrm{O}$ but to different degrees. Extrusion of seeds at $160^{\circ} \mathrm{C}$ reduce trypsin inhibitor activity, improves animal performance, eliminate pancreas hypertrophy, increase pancreas trypsin activity, and improve the morphology of the small intestine (jejunum) in rats. Adding sulphur amino acids $(0.3 \%)$ to the diet with raw soyabean seeds $(10 \%)$ improve performance and the morphology of the jejunum to the highest extent.

\section{REFERENCES}

Bardocz S., Grant G., Ewen S.W.B., Duguid T.J., Brown D.S., Englyst K., Pusztai A., 1995. Reversible effect of plytohaemagglutinin on the growth and metabolism of rat gastrointestinal tract. Gut 37, 353-360

Erlanger B.F., Kokowsky N., Cohen W., 1961. The preparation and properties of two new chromogenic substrates of trypsin. Arch. Biochem. Biophys. 95, 271-278

Iwai K., Fushiki T., Fukuoka S.I., 1988. Pancreatic enzyme secretion mediated by novel peptide: monitor peptide hypothesis. Pancreas 3, 720-728

Jaffe W.G., Scldl D.S., 1992. Toxicology of plant lectins. In: A.T.Tu (Editor). Food Poisoning. Handbook of Natural Toxins. 7, 264-290

Kostyra H., Kostyra E., Krawczuk S., Leontowicz H., 1999. Influence of extrusion of seed lectins on their haemagglutination proporties. Cost 98 European Commission 6, 55-59

Lcontowicz H., Lcontowicz M., Biernat M., Gralak M.A., Krzemiński R., Czerwiński J., 2000. The effect of pea lectins on pancreas and jejunum in rats fed semipurified diet. Effects of antinutrients on the nutritional value of legume diets. Cost 98 European Commission 9, 111-115

Leontowicz H., Leontowicz M., Kostyra H., Gralak M.A., Kulasek G.W., 1999. The influence of extrusion or boiling on trypsin inhibitor and lectin activity in leguminous seeds and protein digestibility in rats. Pol. J. Food Nutr. Sci. 8, 77-87

Lcontowicz H., Leontowicz M., Kostyra H., Kulasck G., Gralak M.A., Krzemiński R., Podgurniak M., 2001. Effects of raw or extruded legume seeds on some functional and morphological gut parameters in rats. J. Anim. Feed Sci. 10, 169-183 
Liener 1.E., 1989. Control of antinutritional and toxic factors in oil seeds and legumes. In: W.E.W. Lusas, D.R. Erikson, W. Nip (Editors). Food Uses of Whole Oil and Protein Seeds. Amer. Oil Chem. Soc., pp. 344-371

Liener I.E., 1994. Implications of antinutritional components in soybean foods. Crit. Rev. Food Sci. Nutr. $34,31-67$

Lowry O.H., Roscbrough A.L., Farr A.J., Randal R.J., 1951. Protein measurement with the folin phenol reagent. J. Biol. Chem. 193, 265-275

Paredes-Lopez O., Guevara-Lara F., Schevenin-Pindeo M.L., Montes-Rivera R., 1989. Comparison of procedure to determine protein content of developing bean seeds (Phaseolus vilgaris). Plant Foods Hum. Nutr. 39, 137-148

Pusztai A., 1993. Dietary lectins are metabolic signal for the gut and modulate immune and hormone functions. Eur. J. Clin. Nutr. 47, 691-699

Valdebouze P., Bergeron E., Gaborit T., Delort-Luval J, 1980. Content and distribution of trypsin inhibitors and heamagglutinins in some legume seeds. Can. J. Plant Sci. 60, 695-701

\section{STRESZCZENIE}

\section{Wplyw dodatku aminokwasów siarkowych do surowych lub ekstrudowanych nasion soi na} wzrost, aktywność trypsyny w trzustce oraz morfologię jelita czczego szczurów

Badano wpływ ckstrudowania nasion soi i dodatku aminokwasów siarkowych (AA) na aktywność inhibitorów trypsyny (TI) oraz lektyn, morfologię i mikrobiologię jelita czczego szczurów. Szczury Wistar karmiono pólsyntetycznymi dietami zawierającymi $10 \%$ nasion soi: surowych lub ekstrudowanych ( $w$ temp. $160^{\circ} \mathrm{C}$ ) bez lub z dodatkiem $0,3 \%$ aminokwasów siarkowych (met+cys). Ekstruzja obniżyła aktywność TI w nasionach z 25,0 do $11,8 \mathrm{TIU} / \mathrm{mg}$, a także aktywność aglutynacji ludzkich erytrocytów z 1:1600 do 1:100 (grupa AB), z 1:800 do 1:50 (grupa A) oraz z 1:800 do 1:100 (grupa 0). Ekstruzja istotnie zwiększyła parametry wzrostowe $(P<0,05)$ i obniżyła względną masę trzustki $(0,40$ vs $0,50 \%$ ), wpłynçła też na wzrost aktywności trypsyny w trzustce (3495 vs 5901 $\mathrm{U} / 100 \mathrm{~g}$ białka), poprawę morfologii jelita czczego i obniżenie liczby $E$. coli. Wpływ AA siarkowych w dictach $z$ udziatem surowych nasion soi na parametry wzrostowe i morfologię jelita był wyraźniejszy niż wpływ ekstruzji. 